\title{
Episodic ataxia type 4
}

INSERM

\section{Source}

INSERM. (1999). Orphanet: an online rare disease and orphan drug data base. Episodic ataxia type 4. ORPHA:79136

Episodic ataxia type 4 (EA4) is a very rare form of Hereditary episodic ataxia (see this term) characterized by late-onset episodic ataxia, recurrent attacks of vertigo, and diplopia. 